\title{
第部 産業界の最近の動向と涳接工学
}

\section{III 構造製 作}

\section{1. 船舶・海洋構造物}

山下泰 生*

Ships and Offshore Structures

by YAMASHITA Yasuo*

キーワード : 造船, 海洋構造物, 溶接, 共通構造規則

\section{1 概 要}

造船市場の需要を表す世界の海上荷動き量は中国を初 めとする新興国を中心とする世界全体の経済発展により 順調に拡大している。これに伴い，世界の新造船竣工量 も順調に増大してきた1)。しかし，図 1 に示すように，海 上荷動き量が 2 倍になる期間に新造船の竣工量は 3 倍以 上に増加している。特に最近数年間の新造船竣工量をみ ると，2006年は前年比 $11 \%$ 増，2007年は前年比 $10 \%$ 増， 2008年は前年比 $18 \%$ 増と急増している。これは将来の経 済発展を見越して実需以上の需要が発生し，韓国，中国 などを中心として急激に設備増強を行い，需要に応じて きたからである。

このような状況は 2008 年 9 月に起こったリーマンショ ックにより大きく変化した。海上輸送に用いられる商船 の価格は中型のものでも数十億円，大型のものでは百億 円を越すので船主は金融機関から融資を受けて船を建造 するのが一般的である。リーマンショック以降，各金融 機関は融資に慎重になり，一気に船主の発注意欲は低下

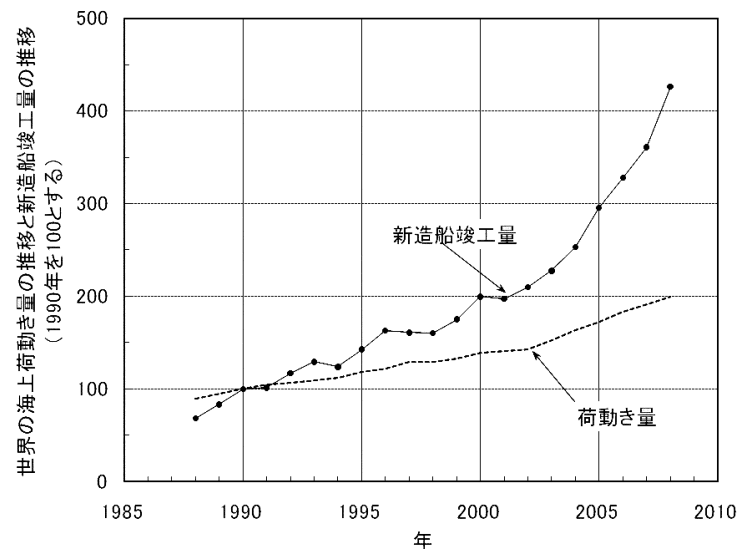

図 1 世界の海上荷動き量と新造船竣工量の推移 [日本造船工業会統計資料より作成］

原稿受付 平成22年4月14日

*正 員 住友重機械マリンエンジニアリング（株） Member, SUMITOMO HEAVY INDUSTRIES MARINE \& ENGINEERING Co., Ltd.
した。このため，造船業界は2008年 9 月以降の受注は激 減している。しかし，世界人口の多数を占める新興国を 中心とした経済発展は続いており，長期的にみれば海上 荷動き量は増大していくと予測されている，そこで，造 船需要もいずれ拡大に転じるはずであるが, 当面は過去 の作り過ぎと過㮃設備による需給ギャップを解消する造 船業界にとっては厳しい調整期間になると考えられてい る。

海洋関係については 2007 年 4 月に海洋基本法が成立 し，2007年 7 月に施行された。これにともない，内閣に 総合海洋政策本部が設置され, 国として海洋政策の総合 的推進体制が整備された，総合海洋政策本部は海洋基本 計画策定作業に着手し，パブリックコメントを経て2008 年 3 月に海洋基本計画が閣議決定された。これにより, 405 万 $\mathrm{km}^{2}$ に及ぶ排他的経済水域（領海を合わせた 200 海 里水域の広さは世界第 6 位の 447 万 $\mathrm{km}^{2}$ ) の開発が推進 される体制が整った22.

\section{2 全体の技術動向}

\subsection{1 船舶関連の規則強化}

（1）共通構造規則（CSR：Common Structural Rule） バルクキャリアーの遭難事故やタンカーの原油流出事 故を契機として，腐食問題・疲労問題が注目され，IMO

(International Maritime Organization：国際海事機 関）を中心に船舶関連の規則が強化されてきた。この流 れに従い，IACS では全船級の統一規則である CSR

(Common Structural Rule : 共通構造規則) が定められ た。この規則は実際に運行する海域に関わらず，すべて の船に海象条件の厳しい北大西洋航路における 25 年就航 に耐える設計と腐食予備厚を要求している。この CSR を 適用すると当然のことながら従来規則を適用した場合に 比較して鋼材重量が増加することになる，そこで，鋼材 重量の増加を少しでも抑制するために耐食性向上と疲労 強度向上のニーズが高まっている.

（2）新塗装基準（PSPC）

バラストタンクの塗装の不備が原因とみられる事故の 対策として, 船の安全確保の目的から腐食防止が義務付 けられた。15年有効な塗装とするために必要な下地処 理，塗装の性能，管理方法などが2006年12月に具体的な 
塗装基準として2006年12月の IMO（国際海事機関）で採 択された。2008年 7 月以降に契約された船には新塗装基 準が強制的に適用されるが，2009年 9 月には新塗装基準 を適用した国内で最初の船が引き渡された3).

\subsection{2 建造量の拡大}

図 2 に示すように2007年までの急激な新造船の受注に 伴う工事量の増大により，各造船所は生産設備の拡充を 行った。日本の造船所はかつての造船不況の教訓から中 国や韓国ほど大規模ではないが，クレーンの大型化やブ ロック工場の新設など工事量増加に対応した設備拡張が 行われた。この結果，ブロックは大型化し，搭載ブロッ クの数を減少させ，ドック期間の短縮が図られた。一 方，韓国や中国では新興造船所の設立やドックの増設な ど大規模な設備増強が行われ，建造能力が急増した。ま た，韓国の大手造船所では設備増強とともに，陸上建造 やフローティングドックを用いた建造など新しい建造方 法が採用された。

\subsection{3 超大型コンテナ船}

コンテナ船は従来，パナマ運河を通過できる最大幅の ものが最大船型であったが，1990年代に入り，パナマ運 河を通過しないオーバーパナマックス船型の出現により 急速に大型化している。最近では積載量が $10,000 \mathrm{TEU}$ と

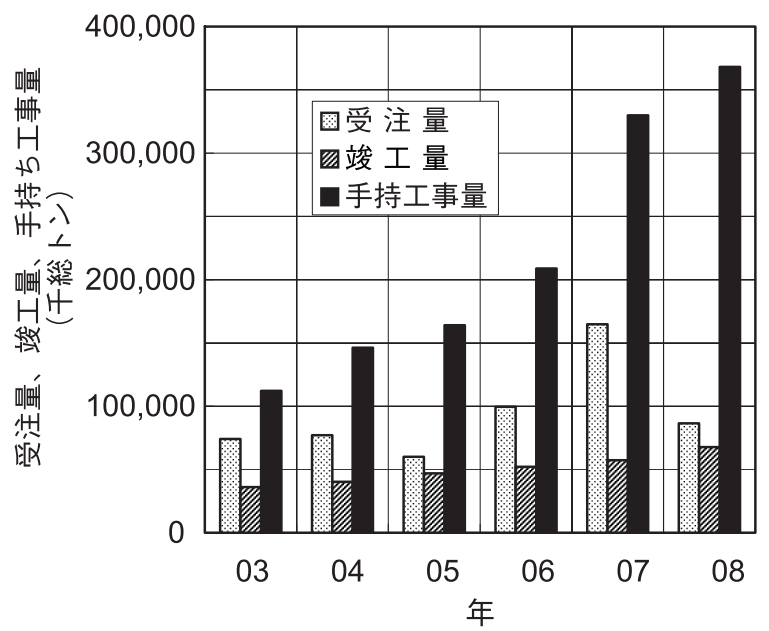

図２世界の新造船受注量，竣工量及び手持ち工事量 [日本造船工業会統計資料より作成］

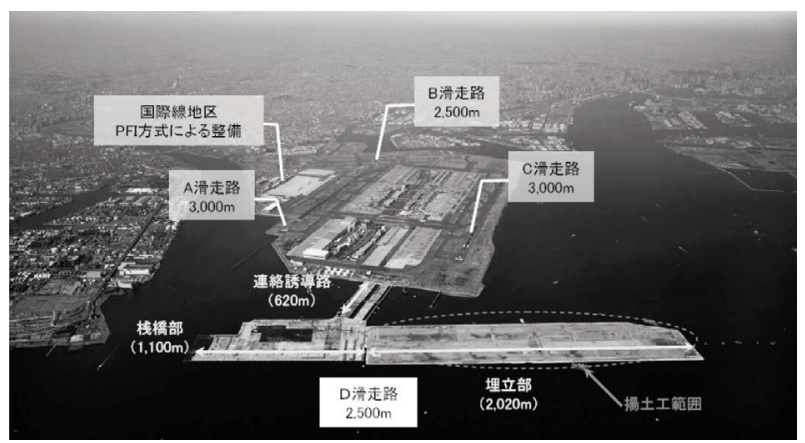

図 3 建設が進む羽田空港新滑走路

（国土交通省関東地方整備局東京空港整備事務所木 ームページ)
いった超大型コンテナ船が建造されている。コンテナ船 は上甲板近傍に縦通部材が少ないので, 縦強度を確保す るため，極厚の高張力鋼が使用される．一般に厚板にな ると勒性值が低下する傾向にあるが, 超大型コンテナ船 で使用される極厚板は従来の船舶の想定を超えているも のであり, 超大型コンテナ船構造安全対策検討委員会 (船舶技術研究協会) などで技術的課題の解決のための 検討が行われた。 また，船級協会でも脆性破壊を防止す る観点からガイドラインが設定された ${ }^{4,5)}$.

\subsection{4 高精度化}

造船において，ブロック精度を確保することが極めて 重要な課題であるが, 精度計測方法やブロック精度のば らつきの原因となる溶接変形についての新たな試みがな されている。

造船ではブロック建造を行っているので，各ブロック について，精度を上げることが重要な課題である。ブロ ックの精度計測方法についてはかつて，トランシット， 巻尺やプロンといった計測器が使用されていたが，現在 では 3 次元計測器を用いるのが主流になっている. 3 次 元計測器では計測したい位置にターゲットを設置してタ ーゲットの 3 次元座標を計測している。すなわち「点」 の計測であるが，最近，レーザースキャナを用いてター ゲットを用いず，「面」での計測が試みられている。

「面」で計測した場合には図面形状との照合をいかに行 うかが重要な課題となる。これに対し，レーザースキャ ンした結果から角の位置を自動的に求め, これを $3 \mathrm{D}$ $\mathrm{CAD}$ による 3 次元形状と照らし合わせることにより効率 よく計測する方法が検討されている ${ }^{6}$. レーザースキャナ の低価格化及び 3 次元 $\mathrm{CAD}$ の進化が進めば曲面の多い 造船の中で今後普及していくことが考えられる.

ブロックを精度よく製作するためには溶接変形を予測 することが重要な課題であることから以前からブロック の溶接変形予測については有限要素法を用いたシミュレ ーションが試みられていた。しかし，大型ブロックの変 形を有限要素法でシミュレーションするためには固有ひ ずみを用いた方法でも多くの要素による大規模な計算が 必要となる。最近, 大型ブロックの組立順序が溶接変形 に及ぼす影響についてのシミュレーションが行われてい る7. 3D-CAD から溶接変形シミュレーションまでの作業 が効率化すれば，事前に施工手順を検討する有力なツー ルになる可能性がある.

\subsection{5 海洋構造物}

現在, 羽田沖では羽田空港の 4 番目の滑走路が平成 2 2 年10月末の供用開始を目指して建設中であるが，多摩 川の河口側は多摩川の流れを阻害しないようにする必要 があり，図 3 に示す写真の栈橋部と連絡誘導路ではパイ プ構造となっている。この部分は現地での工事期間の短 縮等の目的で, 大型のジャケットをつなぎ合せる工法が 採用されている。100 年耐用とするため, 飛沫帯では防食 のため，鋼管表面に板厚 $0.4 \mathrm{~mm}$ の耐海水性ステンレス 鋼（SUS312L）を専用の工場にてライニング溶接してい る ${ }^{8}$. 


\section{3 溶接・接合技術の動向}

1.3.1 共通構造規則（CSR：Common Structural Rule ) への対応

(1) 規則改正に伴う継手構造の変化

CSR の適用が義務付けられたことにより，板厚が増加 し，船款重量は増加する傾向にある。一方, 建造コスト や積載量を考慮すると，船殼重量の増加を抑制する必要 がある。そこで，溶接量は増加するが，図 4 に示すよう に，部分的に疲労強度を必要とする箇所のみの増厚や骨 材の量を増やして対応している造船所が多い。この結 果，溶接としては以下のような構造の変化に対応する必 要が生じてきた。

・板厚差のある板継溶接

・骨材の効率的な製作

・骨材と板の溶接の効率化

・骨材の増加に伴う立向溶接の効率化

(2) 板厚差に対応する板継溶接

造船ではブロック工法が採用されているが，大型ブロ ックのベースとなる板は広幅の鋼材を片面溶接するのが 一般的である。この片面溶接法としては片面サブマージ アーク溶接が多くの造船所で適用されているが，裏波の 形成をフラックスと銅板から得る方法 ( FCB, $\mathrm{FCuB})$ と熱硬化性のフラックスを用いる方法 (RF) が従来から 用いられている。以前は銅板を用いる方法が多く採用さ れてきたが，最近では RF を採用する造船所が増加して いる．片面溶接では板厚差がある場合，上面に後から部 材を取り付けるために，板厚差を下面（董面）に逃がす 場合が多い. RF が銅板を用いる方法よりも板厚差のある 場合の裏波形成が容易であることから導入する造船所が 増加していると考えられる9.

（3）すみ肉溶接の高速化

CSR 適用により骨材が増加する傾向にあるので，この 骨材をいかに効率的に製作するか，また，骨材とベース になる板とのすみ肉溶接をいかに効率的に行うかが重要 な課題となる。このすみ肉溶接について, 内外の数多く の造船所では TOP 法 (Tandem One Pool：2 電極 1 プ ール高速すみ肉溶接法）が採用されている（溶接速度：

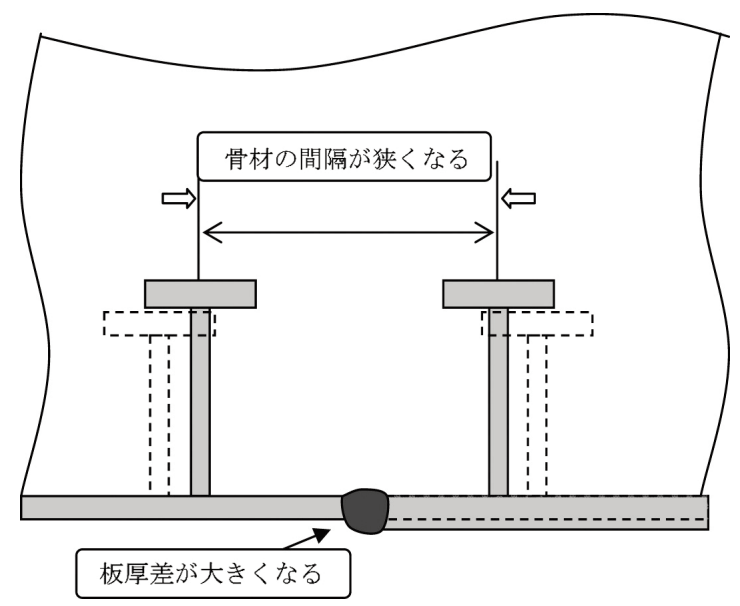

図 4 CSR（共通構造規則）適用による構造变化
$1.0 \mathrm{~m} / \mathrm{min}$ 程度）. しかし，さらなる高速化の要求に対し ては，ビード外観や耐気孔性の点で課題が多い. 図 5 に 示す 3 電極 1 プール高速すみ肉溶接法は, TOP 法の 2 電 極間に専用ワイヤを挿入した新しい溶接施工法である. 挿入電極には, DCEP（直流電極プラス）ではなく，反 対の極性である DCEN（直流電極マイナス）を適用し, 通電するもののアークは発生させない。挿入電極を DCEN にすることで両側の電極と逆の磁界が発生し, アーク干渉が緩和されて溶滴移行および溶融池が安定化 する。これによって品質の安定した高速すみ肉溶接が可 能となった。図 6 ，図 7 に示すように，本溶接法が造船 所のビルトアップロンジ製作ラインとロンジを鋼板に溶 接するラインウェルダーとして導入された ${ }^{10,11)}$.

(4) 立向溶接の効率化

CSR 適用により骨材が増加する傾向にあるので, 結果 として立向溶接も増加する傾向にある。従来，立向姿勢

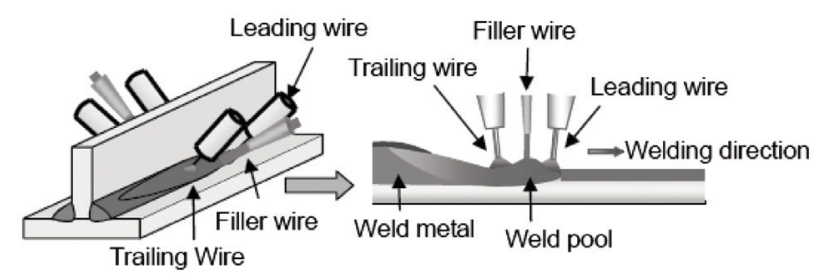

図 53 電極 1 プール高速すみ肉溶接法
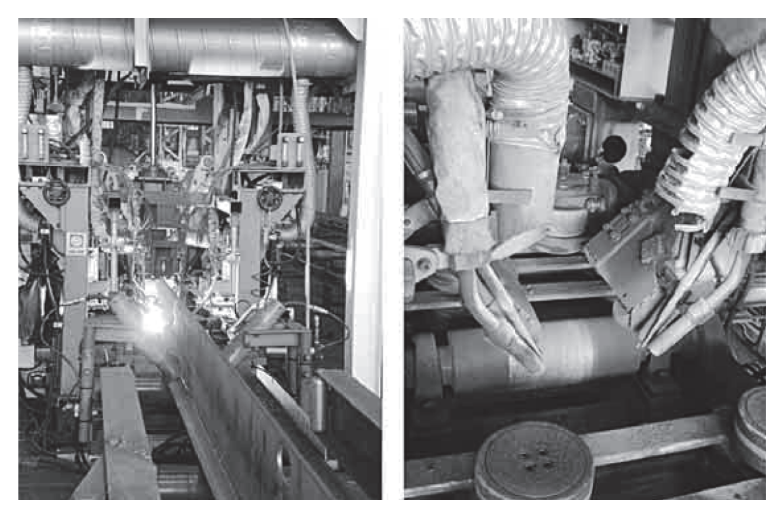

図 63 電極 1プール高速すみ肉溶接を利用したビルト アップロンジ製作ライン

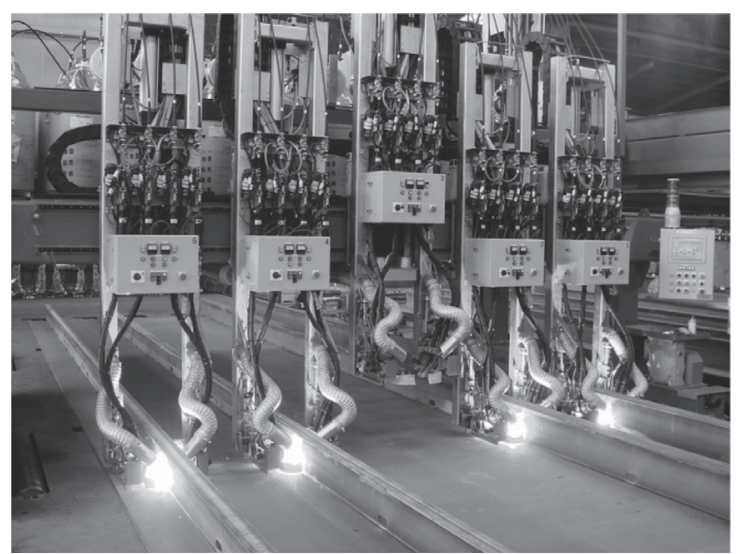

図 73 電極 1 プール高速すみ肉溶接を利用した多電極 溶接装置 


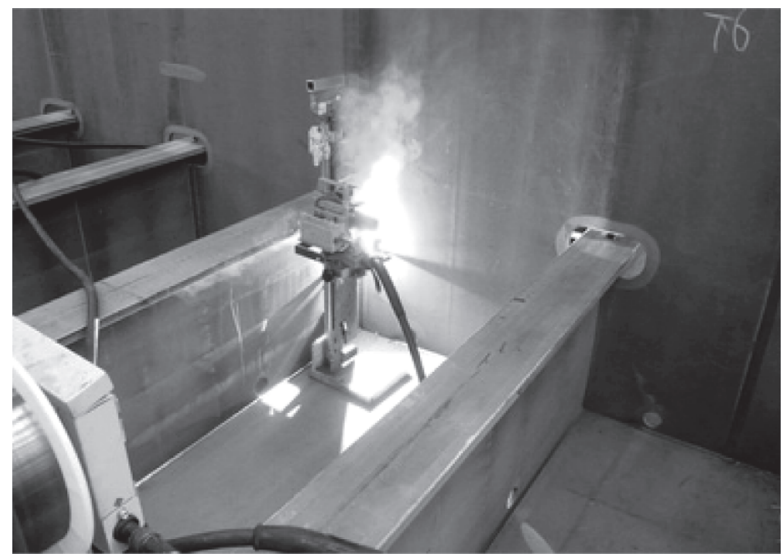

図 8 立向簡易自動溶接機
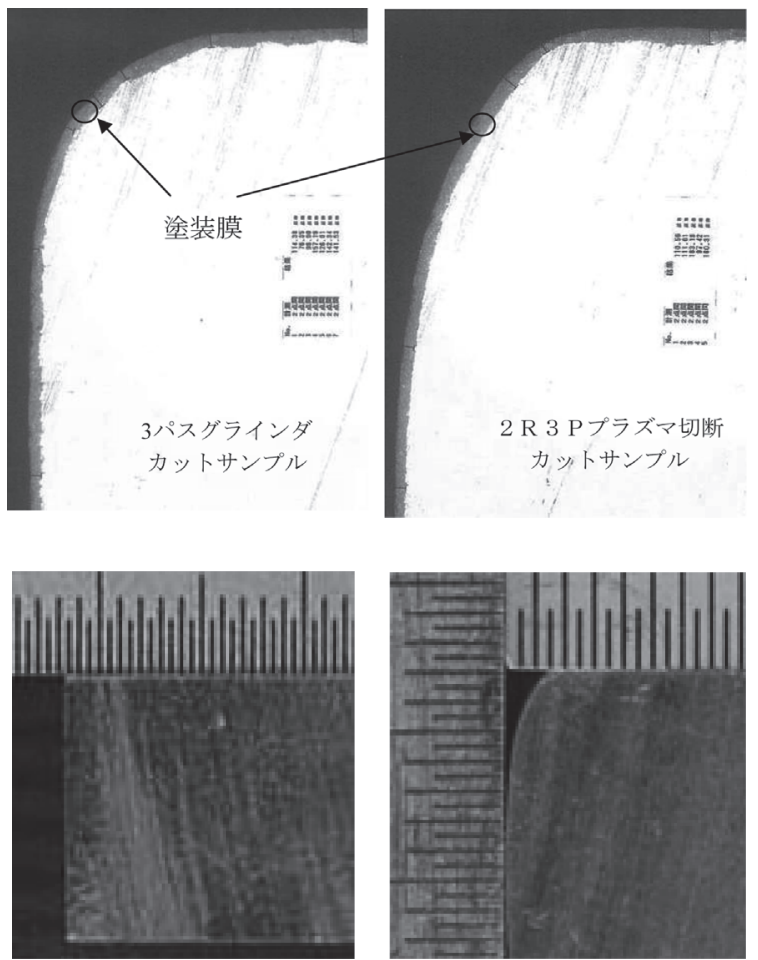

図 9 プラズマ切断機による上面フリーエッジ切断 [小池酸素工業(侏提供]

の溶接ではトーチのウィービングが必要であり, 装置化 する場合においてはロボットなど高度の機能を必要とし ていた。これに対し，溶接金属の粘性やスラグ発生量な どをさらに改良した FCW が開発され，ウィービングを 行わなくても溶接できる立向上進溶接用 $\mathrm{FCW}$ が開発さ れた ${ }^{11}$.この FCW では立向上進溶接でウィービングを行 わない場合でも， $9 \mathrm{~mm}$ 程度の脚長までフラットでなじ
みの良好なビードが得られる。このワイヤを用いること によりウィービング機能を持たない比較的簡易で安価な 装置で立向溶接を機械化することが可能となった。この ような簡易自動溶接装置を使用している例を図 8 に示 す.

\subsection{2 新塗装基準への対応}

新塗装基準ではバラストタンク内のフリーエッジは半 径 $2 \mathrm{~mm}$ 以上の丸みをつける（2R 処理），または 3 回グ ラインダーをかける（3P 処理）必要ある。そこで，この ようなエッジ処理を省力化する方法として図 9 に示すよ うに，切断時に鋼板上面に $2 \mathrm{R}$ 以上の丸みのできるプラ ズマ切断機が開発され ${ }^{12}$, 一部の造船所で使用が開始され た。溶接においても滑らかなスパッターの少ない溶接が 求められ, 溶接材料や溶接機の改良が進められている.

\subsection{3 レーザー・アークハイブリッド溶接}

ヨーロッパの造船所においてはレーザーと GMAW の レーザー・アークハイブリッド溶接が艦艇やフェリーな どの薄板構造で適用されてきた。一般商船建造を中心と する国内の造船所では，適用板厚の制約から導入されて いなかったが溶接変形の防止, 高精度化などを目的とし て $13 \mathrm{~mm}$ 以下の鋼板を対象として, 一般商船への適用が 開始された ${ }^{3,13)}$.レーザー・アークハイブリッド溶接では 従来のアーク溶接と異なる施工管理が必要となる。そこ で，日本海事協会はレーザー・アークハイブリッド溶接 独自の技術要件を反映させ，船体構造に適用する場合の 施工方法承認試験と施工要領作成に関する具体的な要件 を新たなガイドラインとして発行した ${ }^{14)}$. 今後，サンドイ ッチパネルなど，レーザー溶接の特徴を生かした新たな 構造様式が造船の中で普及することが期待される。

\section{文献}

1）造船関係資料，日本造船工業会，2009年 9 月，2）海洋白書2009，海 洋政策研究財団，2009年 5 月。 3) Japan Shipbuilding Digest (No.15), 日本造船工業会，2009年12月．4）大型コンテナ船の YP47 鋼の使用に関 するガイドライン，日本海事協会，2008年10月．5）脆性亀裂アレスト設 計指針，日本海事協会，2009年 9 月．6）レーザースキャナによるブロッ ク精度計測方法に関する研究, 稗方和夫, ワークショップ, 「情報技術に よる海事産業の新展開」，2009年 6 月． 7) 大型溶接構造物の組立・搭載 工程計画に関する研究一船体ブロックの溶接変形予測, 望月正人他, 溶接 学会春季全国大会, 2009年 4 月. 8）東京国際空港 D 滑走路建設外工事 (http://www.haneda-d.jp/d_pr/tec07.html). 9）高品質，高能率を実現 する溶接ソリューション, 伊藤和彦他, 溶接ニュース2009年（平成21年） 9 月22日付. 10) Development and Application of 3-Electrode MAG High Speed Horizontal Fillet Welding Process (IIW DOC. XII-1969-09), Yasuyuki YOKOTA etc., 2009年 7 月. 11) 船舶・海洋 構造物の分野で拡大するフラックス入りワイヤ，伊藤和彦他，神戸製鋼技 報/Vol. 59 No. 1 (Apr. 2009)。12）プラズマ切断の最新技術, 濱田智 他，溶接学会誌 Vol79 (No.2 2010). 13）重工業におけるレーザー加工 技術の動向, 石出孝, 溶接接合振興会第19回セミナー，14）レーザーハ イブリッド溶接ガイドライン, 日本海事協会, 2009年12月. 